\title{
Revised Morphological Characteristics of Species of Two Ostracod Genera Loxoconcha Sars, 1866 (Loxoconchidae) and Xestoleberis Sars, 1866 (Xestoleberididae)
}

Doan Dung Le ( $\nabla$ dungld@hufi.edu.vn )

Ho Chi Minh City University of Food Industry (HUFI)

Research Article

Keywords: Loxoconcha, Mandible, Maxillula, Muscle scar, Xestoleberis

Posted Date: August 24th, 2021

DOI: https://doi.org/10.21203/rs.3.rs-822173/v1

License: (9) This work is licensed under a Creative Commons Attribution 4.0 International License.

Read Full License 


\section{Abstract}

Total 23 species of the genus Loxoconcha and 21 species of the genus Xestoleberis were presented in this study. A scanning electron microscope for observing muscle scars of the carapaces, and a stereoscopic microscope for dissecting, observing and sketching the appendages were used. The results show that most species of the genus Loxoconcha consist of four adductor scars to arrange in a curved sub-vertical row and concave anteriorly, except L. pulchra carrying five, in which the top one is divided into two. The frontal scars with C-shape, opening anteriorly are presented in most of Loxoconcha species, however, the frontal scar with bean-shape or oval-shape is discovered in five species of $L$. japonica group. Most of L. kosugii bear the frontal scar with C-shape, but the frontal scar with $\mathrm{Y}$-shape is found in several individuals. This phenemenon shows the close phylogeny between the genus Loxoconcha and Palmoconcha. About the genus Xestoleberis, chaetotaxy of setae on all appendages, except setae of exopodite on the maxillula is a typical character of this genus. The published fossil records and the tendencies of change in the number of setae on the maxillula and mandible among three phylogenetic groups suggest that Group A or B is an ancestor of the genus Xestoleberis, and Group C is a derived group.

\section{Introduction}

Ostracods are small bivalve crustaceans and living in various aquatic habitats. Their biodiversity is very high, including many different genera and families. Loxoconcha Sars, 1866 (Loxoconchidae) and Xestoleberis Sars, 1866 (Xestoleberididae) are the most diverse ostracod genera. A total of 575 Loxoconcha species and 344 Xestoleberis species have been recorded around the world (Brandão et al. 2015). The members of these two genera are distributed in low to middle latitude areas in marine and brackish waters (Kempf 1986a, 1986b).

The body structure of ostracoda consists of carapaces ouside and soft parts inside. Carapaces of ostracods are closed by adductor muscle scars running through the central part of the body and attached to the inner surface of the calcified outer lamellae (Fig. 1). The adductor scar pattern is another important taxonomic character, particularly useful at superfamily level. As well as a pattern of adductor scars, there may be frontal scars and a pair of "mandibular scars" which are not muscle scars but the points of attachment of chitinous rods which, together with the mandible, form a tripod with its apex butted against a fulcra point on the inside of the valve (Fig. 1) (Horne et al. 2002). In the Ostracoda, carapaces not only give protection against external impact; but also provide some important functions such as respiration and osmoregulation (Yamada et al. 2004). The soft parts of ostracoda are enveloped inside the carapace, so functions such as locomotion and feeding require that the appendages be extended outside the carapace (Tanaka and Tsukagoshi 2013). The maxillula (referred as maxilla or the first maxilla by some authors) is the fourth head appendage of ostracods. It lies immediately behind the mandible and has two main functions, i.e., feeding and, in some groups, respiration (Fig. 2) (Athersuch et al. 1989; Horne et al. 2002). The mandibles are the third pair of appendages and in most ostracods each 
has a strong, heavily sclerotized coxa, provided ventrally with a number of teeth. The main functions of mandibles are for feeding, crawling or digging (Fig. 2) (Athersuch et al. 1989).

The muscle scars of carapace, maxillula and mandible of the soft parts play very important roles in classifying living ostracodas because of their significant taxonomic characters. Therefore, the aims of this paper are to document in comprehensive way morphological characteristics of the muscle scars of the genus Loxoconcha, and of maxillula and mandible of the genus Xestoleberis. These results are useful for taxonomic utility of the two genera.

\section{Materials And Methods}

Samplings were mainly carried out on reef slopes using SCUBA diving, on reef flats, tidal beaches and river mouths during low tide at some localities in the Okinawa Island, Okinawa Prefecture, southern Japan (Fig. 3 and Appendix 1) and in Vietnam (Fig. 4 and Appendix 1). Specifically, two investigations were conducted in the Okinawa Island, one during 9th - 13th May 2013 and the other in the period from 28th May to 2nd June 2014. Two surveys were done in Vietnam, the first at the coast of Ha Long Bay, Quang Ninh province, northern Vietnam in December 2013 and the second at Nha Trang Bay Marine Protected Area, Nha Trang city, central Vietnam and Phu Quoc Marine Protected Area, Kien Giang province, southern Vietnam in November 2014. Additionally, some specimens collected on tidal beaches at some locations around Japan such as Miura, Kanagawa Prefecture; Kisarazu, Chiba Prefecture; Uranouchi Bay, Kochi Prefecture and Miyazaki, Miyazaki Prefecture, Japan by us from 2012 to 2015 or by other members of the laboratory of Shizuoka University, Japan were used in the present study (Fig. 3 and Appendix 1).

In each site (Figs. 3, 4), sediments (sand, rubble dead coral, silt...), sea weeds, sponge... were collected and put into a plastic bottle using a scoop. Superficial sediments were colected from the uppermost $5 \mathrm{~mm}$ of the active layer. Then, all of the collected specimens were fixed in $5-10 \%$ formaldehyde neutralized with hexamethylenetetramine, before being washed through 16-mesh (\# $1 \mathrm{~mm}$ ) and 250-mesh (\# $0.063 \mathrm{~mm}$ ) sieves. Part of the washed material containing ostracods and small sediment was fixed with $70-80 \%$ alcohol for later observations of the appendages, and the remaining material was dried.

All the specimens were dissected under a stereoscopic microscope in the laboratory. Appendages were used to calculate the number of setae on the maxillula, mandible and sketched using a differential interference contrast microscope with a camera lucida (BX-50, OLYMPUS). Dried valves were coated with gold using a quick auto-coater (JFC-1500, lon Sputtering Device) and were then observed with a scanning electron microscope (SEM) (JSM-5600LV, JEOL). SEM photos were used to measure the type of pore on the carapace, the number of adductor scars, the shape of frontal scar...

All the illutrated specimens are deposited in the collections of the Shizuoka University Museum (Japan) and are identified by numbers with the prefix SUM-CO. 


\section{Results And Discussion}

\section{Muscle scars of the genus Loxoconcha}

Muscle scars of a total of 23 species of the genus Loxoconcha were observed in this study (Table 1 and Appendix 2). Most of these species consist of four adductor muscle scars arranging in a weakly curved sub-vertical row or a curved sub-vertical row and concave anteriorly. These are the typical characteristics of genus Loxoconcha (Athersuch and Horne 1984; Athersuch et al. 1989). However, observation of plural individuals of the species $L$. pulchra showed this species carries five adductor muscle scars, in which the top one was divided into two (Appendix 2.13). This character may be a mutation phenomenon that was already mentioned by several authors (e. g., Higashi and Tsukagoshi 2012). It also can be regarded as apomorphy in Loxoconcha. The four adductor muscle scars are normally unequal dimensions with each other, the second scar from the top is much longer than the other in some species, e. g., Loxoconcha sp. 1, L. sp. 9, L. sp. 30, L. mutsuensis, L. modesta, L. harimensis, L. sp. 8 and L. damensis (Appendix 2.2, 4, 68, 10-12). 
Table 1

Characters of muscle scars of 23 species of the genus Loxoconcha

\begin{tabular}{|c|c|c|c|c|}
\hline No. & Species name & Group & Number of adductor scars & Shapes of frontal scar \\
\hline 1 & Loxoconcha shanhaiensis & $A$ & 4 & Bean or oval shape \\
\hline 2 & L. japonica & A & 4 & Bean or oval shape \\
\hline 3 & L. sp. 9 & A & 4 & Bean or oval shape \\
\hline 4 & L. sp. 10 & A & 4 & Bean or oval shape \\
\hline 5 & L. sp. 8 & A & 4 & Bean or oval shape \\
\hline 6 & Loxoconcha sp. 1 & A & 4 & C-shape \\
\hline 7 & L. sp. 30 & A & 4 & C-shape \\
\hline 8 & L. mutsuensis & A & 4 & C-shape \\
\hline 9 & L. modesta & A & 4 & C-shape \\
\hline 10 & L. tosaensis & A & 4 & C-shape \\
\hline 11 & L. harimensis & A & 4 & C-shape \\
\hline 12 & L. damensis & A & 4 & C-shape \\
\hline 13 & L. pulchra & B & $4-5$ & C-shape \\
\hline 14 & L. uranouchiensis & B & 4 & C-shape \\
\hline 15 & L. noharai & B & 4 & C-shape \\
\hline 16 & L. santosi & B & 4 & C-shape \\
\hline 17 & L.sp. 5 & B & 4 & C-shape \\
\hline 18 & L.sp. 4 & B & 4 & C-shape \\
\hline 19 & L. sp. 26 & B & 4 & C-shape \\
\hline 20 & L. kosugii & B & 4 & C-shape and Y-shape \\
\hline 21 & L. sesokoensis & C & 4 & C-shape \\
\hline 22 & L. yoshidai & C & 4 & C-shape \\
\hline 23 & L.sp. 3 & C & 4 & C-shape \\
\hline
\end{tabular}

According to Athersuch and Horne (1984), Athersuch et al. (1989), frontal scars of the genus Loxoconcha are characterized with C-shape. In the present study, most of species of the genus Loxoconcha have the frontal scar with C-shape, opening anteriorly (Table 1 and Appendix 2). However, the frontal scar with bean-shape or oval-shape was discovered in the species of L. japonica group that was distinguished from 
other groups by carapace outlines, surface ornamentation patterns, hinge structures and muscle scar patterns (Tanaka and Ikeya 2002). The Loxoconcha japonica group includes five species L. shanhaiensis, L. japonica, L. sp. 9, L. sp. 10 and L. sp. 8 (Table 1 and Appendix 2.1,3-5, 11) that belong to phytal species and the Group A (Ishii et al. 2005; Le and Tsukagoshi 2014). The novel shapes of frontal scar of the $L$. japonica species group are probably derived from an ancestral shape, i.e., C-shape belonging to the Group B (Ishii et al. 2005; Le and Tsukagoshi 2014). The oldest fossil records of the genus Loxoconcha show that species of Group A have appeared around Japan since the late Pliocene, meanwhile, species of Group B have inhabited areas around Japan since the early Miocene (approximately $18 \mathrm{Ma}$ ) (Yamada et al. 2001; Irizuki et al. 2004; Ishii et al. 2005).

Additionally, there was a variation about the shape of frontal scar in L. kosugii (Table 1, Appendix 2.14 and 3 ) in this study. Most individuals of L. kosugii bear the frontal scar with C-shape (Appendix 3.1-3), but the frontal scar with Y-shape was found in several individuals of this species (Appendix 3.4). The frontal scar with Y-shape is a typical character of the genus Palmoconcha whose phylogeny is close to the genus Loxoconcha (Ishii 2004). The mandibular scar of the Loxoconcha species generally includes two scars with a lengthened circle shape or sub-circle shape. The dimension of two mandibular scars is somewhat equal or unequal each other.

\section{Maxillula, mandible of the genus Xestoleberis and some initial assumptions about evolutionary trend according to the subgroups of this genus}

The maxillula and the mandible of a total of 21 Xestoleberis species were observed in the present study, including 18 species inhabited in Japan coast (including the Okinawa Islands) and 3 species (X. sp. 7, $X$. vietnamensis and $X$. munensis) in Vietnam (Figs. 5, 6, Table 2 and Appendix 1). Also, data on the chaetotaxy of the maxillula and the mandible of 3 species was referred completely from the previous studies, of 5 species were both referred and newed, and of 13 species were showed herein for the first time (Table 2). The checked results of several soft appendages indicated that the number of setae of the outer first podomere of the endopodite on the maxillula ranges from 2 to 5 , of three endites on the maxillula from 11 to 14, of exopodite on the maxillula from 13 to 17 and of the third podomere of mandibular endopodite from 2 to 6 (Table 2). The above morphological characteristics of maxillula and mandible have almost no difference compared to previous studies except the total number of setae of exopodite on the maxillula. Following to Smith et al. (2005), this number of the family Xestoleberididae is 16. 
Table 2

Number of setae of three endites, the 1st podomere of maxillular endopodite, exopodite of the maxillula and the 3rd podomere of mandibular endopodite of 21 species of the genus Xestoleberis

\begin{tabular}{|c|c|c|c|c|c|c|c|}
\hline \multirow[t]{2}{*}{ No. } & \multirow[t]{2}{*}{ Species } & \multirow[t]{2}{*}{ Group } & \multicolumn{3}{|c|}{ Maxillula } & \multirow{2}{*}{$\begin{array}{l}\text { Mandible } \\
\text { 3rd podomere of } \\
\text { mandibular } \\
\text { endopodite }\end{array}$} & \multirow[t]{2}{*}{$N$} \\
\hline & & & $\begin{array}{l}\text { Three } \\
\text { endites }\end{array}$ & $\begin{array}{l}\text { 1st podomere } \\
\text { of maxillular } \\
\text { endopodite }\end{array}$ & $\begin{array}{l}\text { Exopodite } \\
\text { of the } \\
\text { maxillula }\end{array}$ & & \\
\hline 1 & $\begin{array}{l}\text { Xestoleberis } \\
\text { hanaii }^{\mathrm{a}}\end{array}$ & $A$ & 13 & 4 & 17 & 4 & 4 \\
\hline 2 & $X . \mathrm{sp} .1^{\mathrm{a}}$ & A & 13 & 4 & 16 & 4 & 3 \\
\hline 3 & $X . \mathrm{sp} .2^{\mathrm{a}}$ & $A$ & - & - & - & 4 & 2 \\
\hline 4 & $X . \mathrm{sp} .5^{\mathrm{a}}$ & $A$ & 12 & 4 & - & - & 4 \\
\hline 5 & $X . \mathrm{sp} .6^{\mathrm{a}}$ & $A$ & - & 4 & - & 4 & 2 \\
\hline 6 & $X . s p .7^{a}$ & A & 14 & 5 & 16 & 4 & 2 \\
\hline 7 & $\begin{array}{l}X . \\
\text { vietnamensis }\end{array}$ & $A$ & 13 & 4 & 16 & 4 & 5 \\
\hline 8 & $X$. munensis $^{\mathrm{a}}$ & A & 14 & 4 & $17-18$ & 4 & 6 \\
\hline 9 & $\begin{array}{l}X . \\
\text { magutiensis }{ }^{\mathrm{a}, \mathrm{b}}\end{array}$ & A & 12 & 4 & 13 & 4 & 2 \\
\hline 10 & X. kamiya $a^{\mathrm{a}, \mathrm{b}}$ & A & 11 & 4 & 15 & 4 & 2 \\
\hline 11 & X. ikeya $a^{\mathrm{a}, \mathrm{c}}$ & A & 11 & 4 & 17 & 4 & 2 \\
\hline 12 & $X$. planuventer $^{\mathrm{a}}$ & A & - & 3 & 17 & 4 & 5 \\
\hline 13 & X. ryukyuensis ${ }^{\mathrm{a}}$ & A & 14 & 4 & 17 & 4 & 4 \\
\hline 14 & $X$. sesokoensis $^{\mathrm{a}}$ & $A$ & 12 & 4 & 17 & 4 & 3 \\
\hline 15 & $\begin{array}{l}X . \\
\text { setouchiensis }^{\mathrm{a}, \mathrm{d}}\end{array}$ & A & 11 & 4 & 16 & 4 & 2 \\
\hline 16 & X. kuroshio ${ }^{\mathrm{a}}$ & B & 11 & 4 & 17 & 6 & 5 \\
\hline 17 & X. magnoculus ${ }^{\mathrm{a}}$ & $B$ & 13 & 4 & 17 & 6 & 3 \\
\hline 18 & $X$. notoensis ${ }^{\mathrm{a}, \mathrm{c}}$ & C & - & 2 & 16 & 2 & 2 \\
\hline
\end{tabular}

Note: (a) - This study; ${ }^{(b)}$ - Hirosaki (2013); (c) - Sato \& Kamiya (2007); (d) - Okubo (1979) 


\begin{tabular}{|c|c|c|c|c|c|c|c|}
\hline \multirow[t]{2}{*}{ No. } & \multirow[t]{2}{*}{ Species } & \multirow[t]{2}{*}{ Group } & \multicolumn{3}{|c|}{ Maxillula } & \multirow{2}{*}{$\begin{array}{l}\text { Mandible } \\
\text { 3rd podomere of } \\
\text { mandibular } \\
\text { endopodite }\end{array}$} & \multirow[t]{2}{*}{$N$} \\
\hline & & & $\begin{array}{l}\text { Three } \\
\text { endites }\end{array}$ & $\begin{array}{l}\text { 1st podomere } \\
\text { of maxillular } \\
\text { endopodite }\end{array}$ & $\begin{array}{l}\text { Exopodite } \\
\text { of the } \\
\text { maxillula }\end{array}$ & & \\
\hline 19 & $\begin{array}{l}X . \\
\text { sagamiensis }^{\mathrm{C}}\end{array}$ & C & 14 & 2 & $16-17$ & 2 & \\
\hline 20 & $X$. ishizakiic & C & - & 2 & - & 2 & \\
\hline 21 & X. iturupica ${ }^{\mathrm{c}}$ & C & - & 2 & - & 2 & \\
\hline Note & - This study; & lirosak & 013); (c) & Sato \& Kamiva & 7); (d) - Oku & (1979) & \\
\hline
\end{tabular}

Based on the combination of the morphological types of pore systems (Sato and Kamiya 2007), the 21 species of Xestoleberis were divided into three groups. The Group A has both sieve-type and lip-type pores and comprises 15 species. The Group B has only sieve-type pore, and consists of two species. The Group $C$ has simple-type and sieve-type pores and includes four species (Table 2). The pore types of the genus Xestoleberis were referred from Puri (1974). The number of setae of the first podomere of maxillulan endopodite is low in the Group C (average of 2 setae) and high in the Group B (average of 4 setae) and the Group A (average of 4 setae). The number of setae of the third podomere of the endopodite on the mandible is constant among species of each group, and this number is low in the Group C ( 2 setae), median in the Group A (4 setae) and high in the Group B ( 6 setae). On the other hand, the total number of setae of three endites and of exopodite on the maxillula varies among species within each group, and there are no differences in the two characters among three groups (Table 2).

The old records of Xestoleberis worldwide (and the assignment of the species group based on their carapace morphology) include: $X$. sp. 1 (Group A) from the Barremian, France (Babinot et al. 1985); $X$. minuta (Group A) from the upper Cretaceous Rosario Formation, U.S.A, East Pacific Ocean (Holden 1964); X. opina (Group B) from the Campanian Ozan Formation, U.S.A (Brouwers and Hazel 1978); X. convexa (Group B) from the Thanetian, France (Ducasse et al. 1985); $X$. tunisiensis (the Group A) from the late Paleocene, Egypt (Bassiouni and Morsi 2000). Up to now, no fossil record of the Group $C$ has been found yet. The above fossil records and the tendencies of change in the number of setae on the maxillula and mandible suggest that geologic age of the Group $A$ and $B$ is older than that of the Group $C$ and the Group $\mathrm{A}$ or $\mathrm{B}$ is an ancestor of the genus Xestoleberis, and the Group $\mathrm{C}$ is a derived group. Hence, a phylogenetic trend of the genus Xestoleberis is shown: among the different species of this genus, the smaller number of setae of outer first podomere of maxillulan endopodite as well as the number of setae of the third podomere of madibular endopodite are probably distributed in the species of the derived taxonomic group.

\section{Declarations}




\section{ACKNOWLEDGEMENTS}

We thank Prof. Akira Tsukagoshi (Shizuoka University, Japan), Prof. Takahiro Kamiya and Dr. Tohru Ishii (Kanazawa University, Japan) for their invaluable advice and continuous encouragement. We also appreciate Dr. Hayato Tanaka (University of Tokyo, Japan) and the members of the Ostracod Research Team of Shizuoka University for helpful comments and assistance. Thanks also go to Research Institute for Marine Fisheries, the Provincial People's Committees of Khanh Hoa and Kien Giang for their help during our field trips in Vietnam. Finally, we are deeply grateful to the editor and the reviewers who carefully reviewed our manuscript.

\section{References}

1. Athersuch, J. \& Horne, D. J. A review of some European genera of the Family Loxoconchidae (Crustacea: Ostracoda). Zoological Journal of the Linnean Society, 81, 1-22 (1984). 10.1111/j.10963642.1984.tb02557.x

2. Athersuch, J., Horne, D. J. \& Whittaker, J. E. Marine and Brackish Water Ostracods. Synopses of the British Fauna (new series) 43, 359pp(1989).

3. Babinot, J. F. et al. Crétacé inférieur in Atlas des Ostracodes de France (ed. Oertli, H. J.) 9, 163-209 (Bulletin des Centres de Recherches Exploration-Production Elf-Aquitaine, 1985).

4. Bassiouni, M. A. \& Morsi, A. M. Paleocene-Lower Eocene ostracodes from El Quss Abu Said Plateau (Farafra Oasis), western Desert, Egypt. Paleontographica (A), 257, 27-84 (2000).

5. Brandão, S. N. et al. World Ostracoda Database. Preprint http://www.marinespecies.org/aphia.php? $\mathrm{p}=$ taxdetails\&id=127643 (2015).

6. Brouwers, E. M. \& Hazel, J. E. Ostracoda and correlation of the Severn Formation (Navarroan: Maestrichtian) of Maryland. Paleontology, 52 (6), 1-52 (1978).

7. Ducasse, O., Guernet, C., Tambareau, Y. \& Paléogéne in Atlas des Ostracodes de France (ed. Oertli, H. J.) 9, 163-209 (Bulletin des Centres de Recherches Exploration-Production Elf-Aquitaine 1985).

8. Higashi, R. \& Tsukagoshi, A. Two new species of the interstitial genus Parvocythere (Crustacea, Ostracoda, Cytheroidea) from Japan: an example of morphological variation. Zookeys, 193, 27-48 https://doi.org/10.3897/zookeys.193.2842 (2012).

9. Hirosaki, M. Taxonomy of two new species of ostracod gene Xestoleberis and study about the stages of an interstitial adaptation. Unpublished Master's thesis, Shizuoka University, 17 pp(2013) [in Japanese with English abstract].

10. Holden, J. C. Upper Cretaceous ostracods from California., 7, 3393-3429 (1964).

11. Horne, D. J., Cohen, A. \& Martens, K. Taxonomy, morphology and biology of Quaternary and living ostracoda in The ostracoda: Applications in Quaternary Research (eds. Holmes, J. A. \& Chivas, A.)636(American Geophysical Union, Washington DC, 2002). 
12. Irizuki, T., Yamada, K., Maruyama, T. \& Ito, H. Paleoecology and taxonomy of Early Miocene ostracoda and paleoenvironments of the eastern Setouchi province, central Japan., 50 (2), 105-147 (2004).

13. Ishii, T. Phylogeny and evolution of the genus Loxoconcha and ralated genera (Ostracoda, Crustacea). Doctoral Thesis of Kanazawa University, Japan(2004).

14. Ishii, T., Kamiya, T. \& Tsukagoshi, A. Phylogeny and evolution of Loxoconcha (Ostracoda, Crustacea) species around Japan., 538, 81-94 https://doi.org/10.1007/s10750-004-4939-3 (2005).

15. Kempf, E. K. Index and Bibliography of Marine Ostracoda, 1, Index A. Geologisches Institut der Universität Köln. Sonderveroeffentlichungen No, 50, 1-762 (1986a).

16. Kempf, E. K. Index and Bibliography of Marine Ostracoda, 2, Index B. Geologisches Institut der Universität Köln. Sonderveroeffentlichungen No, 51, 1-708 (1986b).

17. Le, D. D. \& Tsukagoshi, A. Three new species of the genus Loxoconcha (Crustacea, Ostracoda, Podocopida) from the Okinawa Islands, southern Japan. Zootaxa, 3796, 147-165 https://doi.org/10.11646/zootaxa.3796.1.7 (2014).

18. Okubo, I. Three species of Xestoleberis (Ostracoda) from the Inland Sea of Japan. Proceedings of the Japanese Society of Systematic Zoology 16, 8-16; 10.19004/pjssz.16.0_9 (1979).

19. Okubo, I. A new species of the genus Xestoleberis from Japan.Special Publication of the Mukaishima Marine Biological Station,123-126(1985).

20. Puri, H. S. Normal pores and the phylogeny of Ostracoda. Geoscience and Man, 6, 137-151 (1974).

21. Sars, G. O. Oversigt af Norges marine Ostracoder. Forhandlinger i Videnskabs-Selskabet i Christiania, 8, 1-130 (1866).

22. Sato, T. \& Kamiya, T. Taxonomy and geographical distribution of recent Xestoleberis species (Cytheroidea, Ostracoda, Crustacea) from Japan. Paleontological Research, 11, 2183-2227 10.2517/1342-8144(2007)11[183:TAGDOR]2.0.CO;2 (2007).

23. Smith, R. J., Kamiya, T., Horne, D. J. \& Tsukagoshi, A. Evaluation of a new character for the phylogenetic analysis of Ostracoda (Crustacea): the podocopan maxillular branchial plate., 243, 139-153 https://doi.org/10.1016/j.jcz.2004.07.005 (2005).

24. Tanaka, G. \& Ikeya, N. Migration and speciation of the Loxoconcha japonica species group (Ostracoda) in East Asia. Paleontological Research, 6, 3265-3284 https://doi.org/10.2517/prpsj.6.265 (2002).

25. Tanaka, H. \& Tsukagoshi, A. The toxonomic utility of the male lip morphology in the ostracod genus Parapolycope (Crustaces), with description of two new species. Journal of Natutal History, vol. 47, Nos.13-16, 963-986; 10.1080/00222933.2012.743615 (2013).

26. Yamada, K., Irizuki, T. \& Nakajima, S. Spatial and temporal distribution of fossil ostracodes assemblages and sedimentary facies in the Lower Miocene Arakida Formation, Tomikusa Group, Nagano Prefecture, central Japan. J. Geol. Soc. Japan, 107, 1-13 (2001). [in Japanese with English abstract]. 
27. Yamada, S., Tsukagoshi, A. \& Ikeya, N. Ultrastructure of the carapace in some Semicytherura species (Ostracoda: Crustacea). Micropaleontology, vol. 50, no. 4, 381-389; 10.1661/00262803(2004)050[0381:UOTCIS]2.0.C0;2(2004).

\section{Figures}

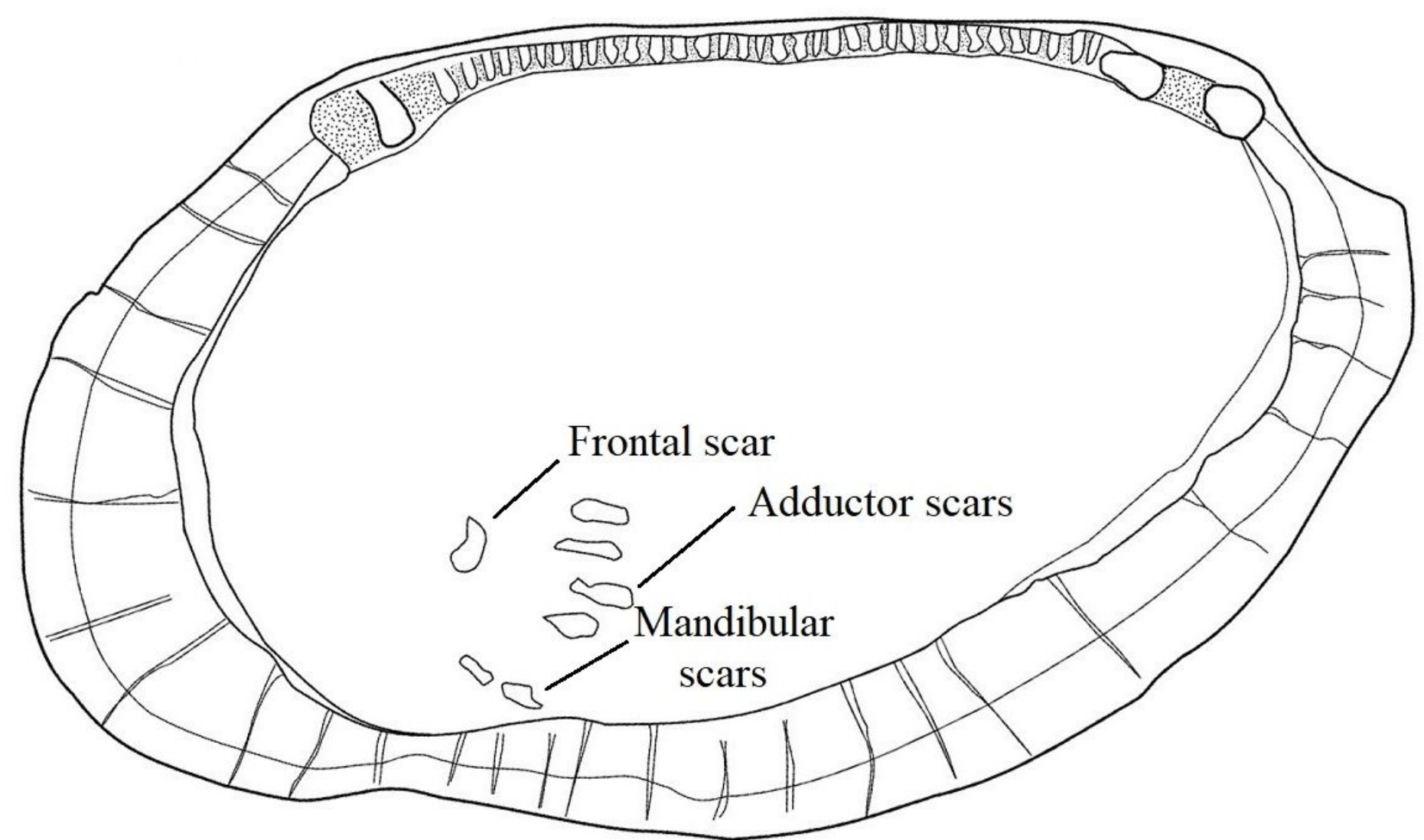

Figure 1

Sketching of male right valve in internal lateral view of carapace of Loxoconcha damensis (adult male) indicating the adductor scars, mandibular scars and frontal scar. Scale: $200 \mu \mathrm{m}$ 


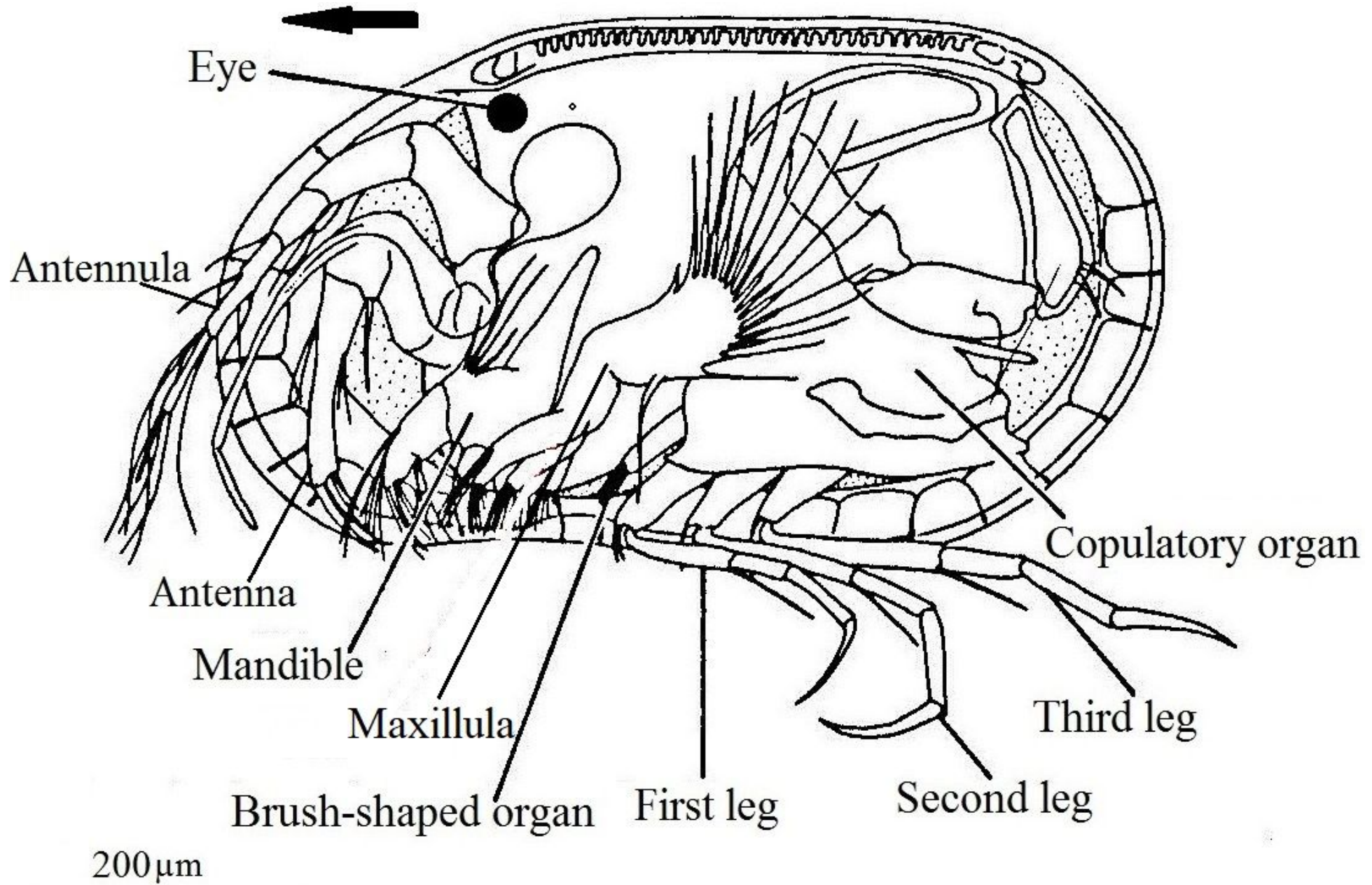

Figure 2

Loxoconcha elliptica (adult male), seen from the left side with left valve removed, to show the general arrangement of the appendages (only one of each pair of appendages shown for clarity) (Athersuch et al. 1989) 


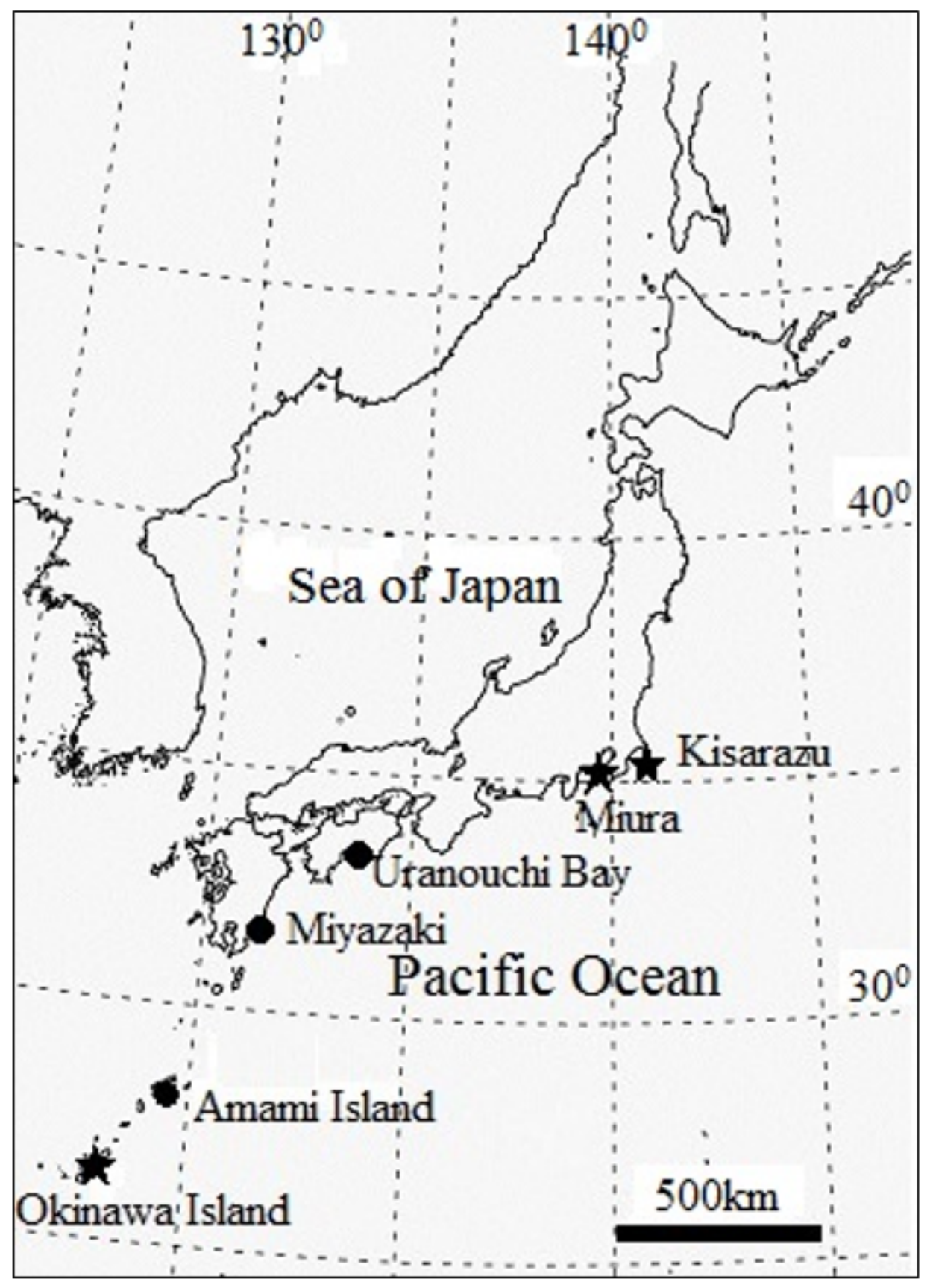

Figure 3

Study sites in Japan. Details of occurrence are shown in Appendix 1. Star shapes (Sampling and using ready specimens), solid circles (Only using ready specimens). 


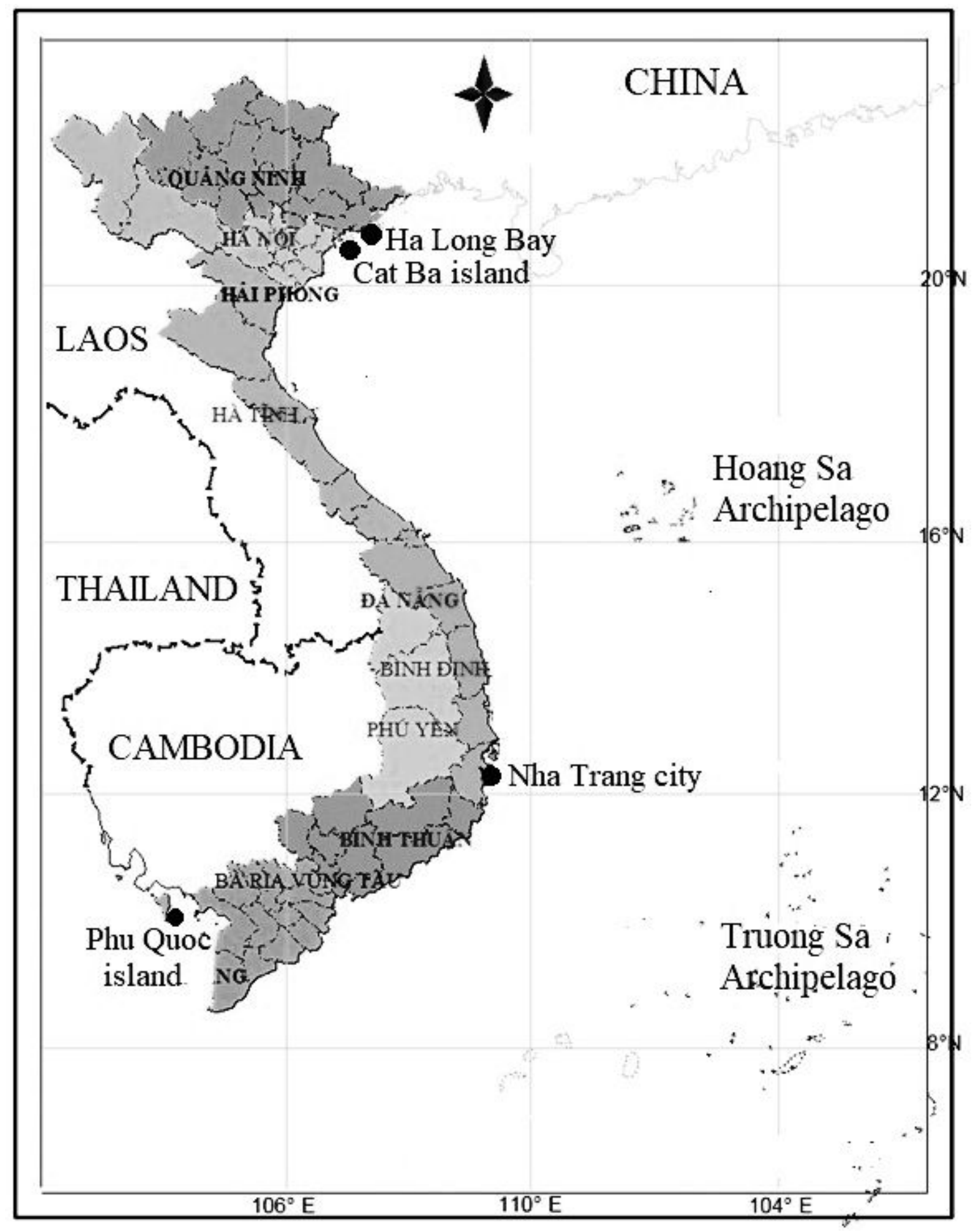

Figure 4

Map of Vietnam showing four surveyed areas with solid circles, Phu Quoc Island, Nha Trang Bay, Ha Long Bay and Cat Ba Island 


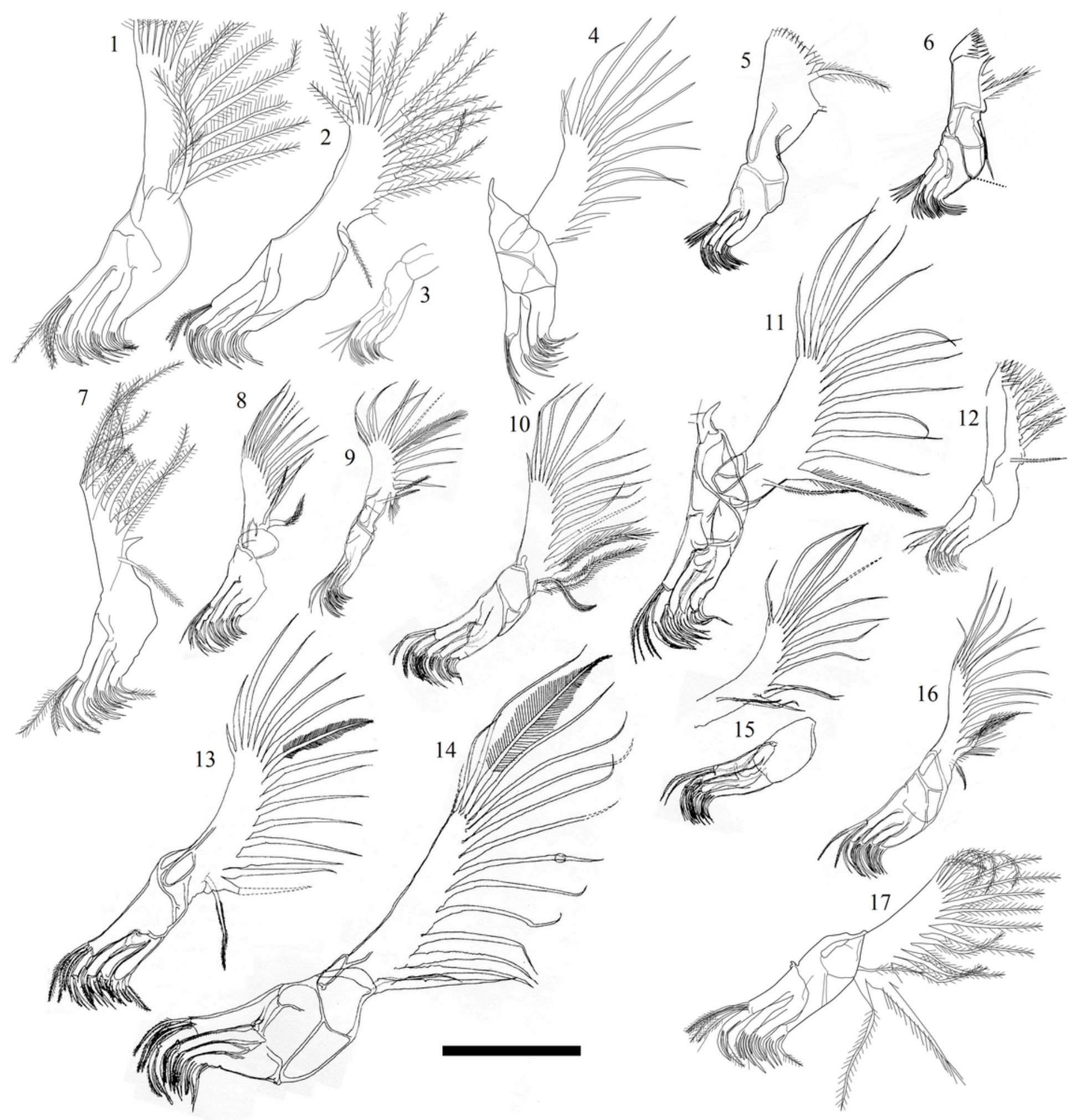

\section{Figure 5}

Adult maxillula in 17 species of the genus Xestoleberis. 1, X. hanaii (male); 2, X. sp. 1 (female); 3, X. sp. 5 (male); 4, X. sp. 7 (male); 5, X. maguitiensis; 6, X. kamiya; 7, X. vietnamensis; 8, X. ikeya (male); 9, X. planuventer (male); 10, X. ryukyuensis (male); 11, X. sesokoensis (male); 12, X. setouchiensis (male); 13 , X. kuroshio; $14, X$. magnoculus (male); $15, X$. notoensis (male); $16, X$. sagamiensis (male); $17, X$. 
munensis (male). Note: 5, after Hirosaki (2013); 12, after Okubo (1979); 15, 16, after Sato and Kamiya (2007). Scale: $100 \mu \mathrm{m}$.

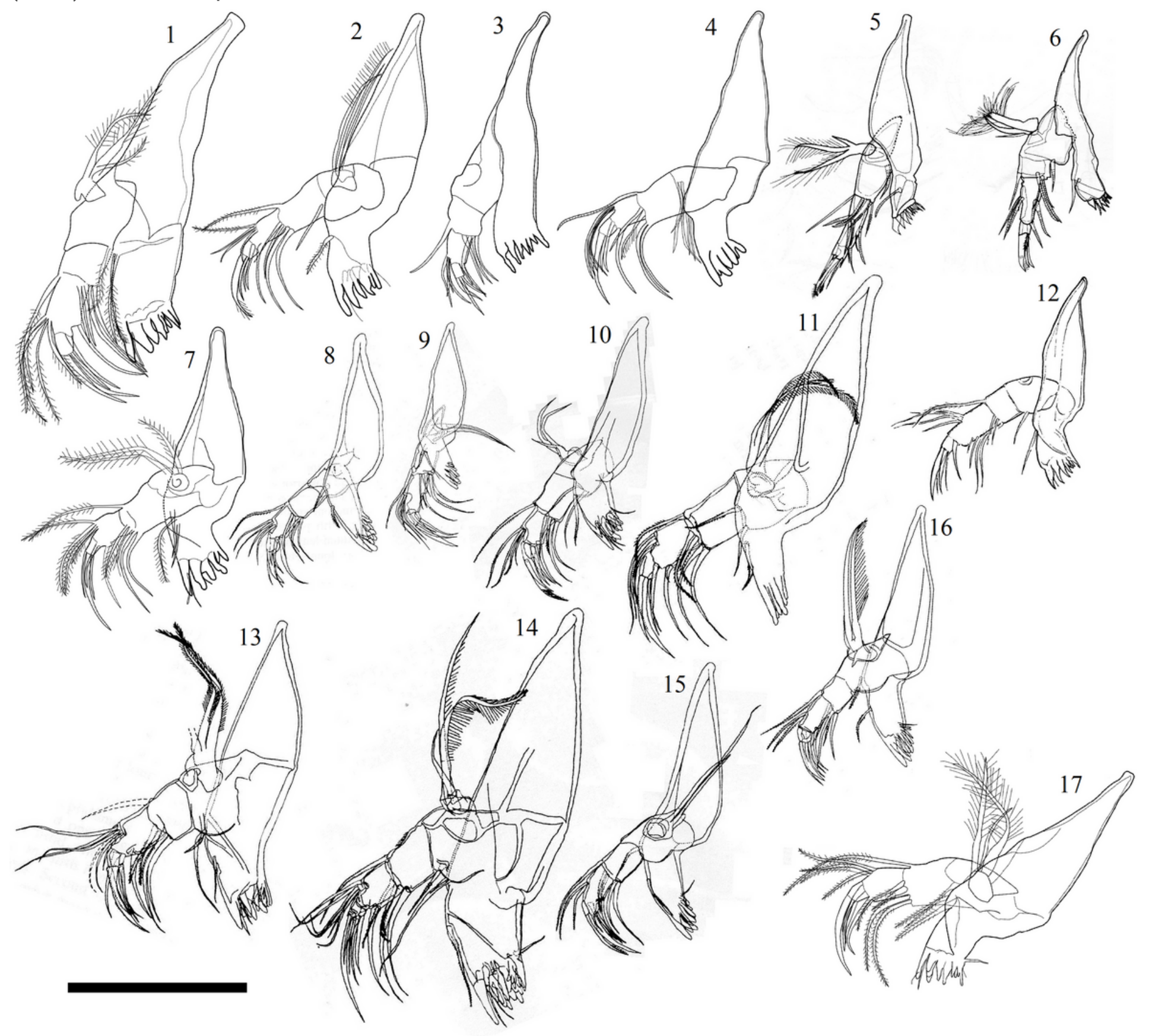

Figure 6

Adult mandible in 17 species of the genus Xestoleberis. 1, X. hanaii (male); 2, X. sp. 1 (female); 3, X. sp. 6 (male); 4, X. sp. 7 (male); 5, X. magutiensis; 6, X. kamiya; 7, X. vietnamensis (male); 8, X. ikeya (male); 9, X. planuventer (male); 10, X. ryukyuensis (male); 11, X. sesokoensis (male); 12, X. setouchiensis (male); 13 , X. kuroshio; $14, X$. magnoculus (male); $15, X$. notoensis (male); 16, X. sagamiensis (male); $17, X$. munensis (male). Note: 5, 6, after Hirosaki (2013); 12, after Okubo (1979); 15, 16, after Sato and Kamiya (2007). Scale: $100 \mu \mathrm{m}$. 


\section{Supplementary Files}

This is a list of supplementary files associated with this preprint. Click to download.

- Appendices.docx

- Appendix2.png

- Appendix3.png 